\title{
A SHORT HISTORY OF WESTERN LEGAL THEORY BY JM KELLY
}

\author{
Sandra Petersson*
}

J M Kelly A Short History of Western Legal Theory (reprint, Clarendon Press, Oxford, 1997) (466 + xvi pages, \$75).

First published in 1992, JM Kelly's A Short History of Western Legal Theory is not, strictly speaking, a new book. However, as evidenced by five reprintings in its first five years, it is a book that continually attracts new readers and rightly so. It is a masterfully readable book, a quality often neglected in the area of legal theory. Though published posthumously, the manuscript was virtually complete when Kelly died in 1990. Tony Honoré took on the task of checking the text prior to publication, with missing references supplied by Ernest Metzger.

In the Foreword, Ronan Keane notes that Kelly's "primary concern ... was to make us see jurisprudence in its historical setting" and he achieves this goal with relative ease. ${ }^{1}$ Kelly takes Bertrand Russell's History of Western Philosophy as his model and ably constructs "a simple, chronological account of the legal theories produced by, and in their turn influencing, the main epochs of Western history." 2

As Kelly explains, the book is "divided into ten chapters dealing with ten slices of the time separating Homer's world from that of Gorbachov."3 Kelly follows the usual manner of carving this 2,500 year period into manageable portions. Chapter One addresses the Greeks, while Chapter Two turns to the Romans. Chapters Three and Four divide the early and the

* Lecturer in Law, Victoria University of Wellington.

1 J M Kelly A Short History of Western Legal Theory (Oxford University Press, Oxford, 1992) vi.

2 Kelly, above $\mathrm{n} 1$, xii.

3 Kelly, above n 1, xiii. 
high Middle Ages at 1100. Chapter Five combines the Renaissance and Reformation, bringing the survey up to 1600 . The 17th, 18th, and 19th centuries are the subject of the next three chapters. Chapters Nine and Ten take on "the profusion of new legal theory" produced in the 20th century. ${ }^{4}$

Kelly traces a number of key themes through each of these eras, although the lack of a more detailed Table of Contents conceals the elegant structure of his chronology. Each chapter begins with a general historical introduction, presenting the reader with the overall political, social, and cultural context of the period. Kelly then examines how the period's legal theory approached and influenced certain key themes. The key themes he traces are: Theory of the State, Validity of Law, Rule of Law, Nature and Purpose of Law, Natural Law, Equality, Property, Equity, Criminal Law and Punishment, and International Law. This structure is of great assistance to the reader who wishes to trace the 2,500 year evolution of a particular theme such as Natural Law. However, Kelly's survey of each period is not restricted to these themes to the exclusion of other significant developments, such as the need for specific comments on the Emergence of New Constitutional Themes in the 18th century. Kelly also allows for the natural substitution of themes over time; while Slavery is a key theme followed in earlier chapters, it gives way to a discussion of Natural Rights from the 17th century onwards.

Kelly's work is notably non-Anglocentric, a bias found in many other English language surveys of jurisprudence. He gives due weight to both common law and civilian theorists. As such, the book also operates as a bridge for both common lawyers and civilians seeking to expand their understanding of the other tradition.

Kelly's treatment of two legal theories warrants specific comment. The first is his treatment of positivism. Positivism is almost entirely dealt with as an aside to natural law theory, rather than as a separate conception of law. Though intended as a student textbook, the novice reader is likely to miss the full context and significance of positivism, which has not even been granted an entry in the index. ${ }^{5}$ While Kelly does discuss positivism, though somewhat inaccessibly, he omits all mention of feminist legal theories. A single passing reference to John Stuart Mill's The Subjection of Women (1869) is an inadequate history of feminist theories emerging in the late 19th century and throughout the 20th century. Kelly's omission of feminist

4 Kelly, above $\mathrm{n} 1,358$.

5 Though no doubt beyond Kelly's control, the index is often inadequate. For example, it does not refer to Coke or Bracton, though both are discussed at several points. 
legal theories also creates a misleading summary of 20th century jurisprudence by not noting serious challenges to modern theories such as rights analysis or law and economics.

At the juncture of the 20th and 21st centuries, we live in a culture that increasingly views knowledge as consumable product. The Nutshell Nineties have served up all manner of intellectual fast foods to meet the craving for quick comprehension. The field of jurisprudence has been no exception, though so far we have been spared such titles as Legal Theory for LayAbouts, Natural Law for Ninnies, and Positivism for Posers. Kelly's Short History of Western Legal Theory does not belong to this category of instant mental make-overs. It is a book that demands the reader's sustained attention but it is also a book that rewards such attention. 
(2000) 31 VUWLR 